\title{
STRATEGI KEPALA MADRASAH DALAM PENGEMBANGAN KOMPETENSI PROFESIONAL GURU UNTUK MENINGKATKAN MUTU PENDIDIKAN
}

\author{
Roudhatul Jannah \\ IAIN Syekh Nurjati Cirebon \\ rjannah657@gmail.com

\section{Huriyah} \\ IAIN Syekh Nurjati Cirebon \\ 61.huriyah@gmail.com
}

\begin{abstract}
Education has a strategic role in preparing the younger generation. Improving the quality of human resources must start early and can be achieved if schools are able to provide qualified and professional educators. Educators are at the forefront of creating quality of education. Educators deal directly with students in class through the teaching and learning process. Thus, a professional educator clearly must have certain skills that are obtained through a special education or training process, and there is an element of devotion (professional calling) in carrying out a job. Based on the principles of professionalism, the empowerment of the teaching profession is carried out through self-development that is carried out in a democratic, fair, non-discriminatory and sustainable manner by upholding human rights, religious values, cultural values, national diversity and professional code of ethics. Thus, educators in addition to their main duties in the classroom must also have the opportunity to develop themselves according to what is stated in Article 14, namely to receive training and professional development in their fields.
\end{abstract}

Keywords: principal strategy; teacher competency development, quality of education;

\begin{abstract}
Abstrak
Pendidikan memiliki peranan strategis untuk mempersiapkan generasi muda yang tinggi. Peningkatan kualitas sumber daya manusia harus dimulai sejak dini dan dapat terjuwud jika sekolah mampu menyediakan para pendidik yang berkualitas dan profesional. Pendidik berada di barisan terdepan dalam menciptakan mutu pendidikan. Pendidik berhadapan langsung dengan para peserta didik di kelas melalui proses belajar mengajar. Dengan demikian, seorang pendidik yang profesional jelas harus memiliki keahlian tertentu yang diperoleh melalui sebuah proses pendidikan maupun pelatihan khusus, dan terdapat unsur semangat pengabdian (panggilan profesi) dalam melaksanakan suatu pekerjaan. Berdasarkan prinsip profesionalitas maka pemberdayaan profesi pendidik diselenggarakan melalui pengembangan diri yang dilakukan secara demokratis, berkeadilan, tidak diskriminatif, dan berkelanjutan dengan menjunjung tinggi hak asasi manusia, nilai keagamaan, nilai kultural, kemajemukan bangsa dan kode etik profesi. Dengan demikian pendidik disamping tugas pokoknya di dalam kelas juga harus mendapat kesempatan untuk mengembangkan dirinya sesuai dengan yang tercantum dalam pasal 14 yaitu memperoleh pelatihan dan pengembangan profesi dalam bidangnya.
\end{abstract}

Kata Kunci: Strategi kepala madrasah; pengembangan kompetensi guru; mutu pendidikan 


\section{PENDAHULUAN}

Pendidikan memiliki peranan strategis untuk mempersiapkan generasi muda yang tinggi. Peningkatan kualitas sumber daya manusia harus dimulai sejak dini dan dapat terjuwud jika sekolah mampu menyediakan para pendidik yang berkualitas dan profesional. Selain itu secara terus menerus pendidik mengembangkan profesionalitasnya sesuai dengan perkembangan kemajuan ilmu pengetahuan. Kebijakan program untuk meningkatkan mutu pendidikan meliputi tiga aspek utama, yaitu: pertama, pengembangan kurikulum berkelanjutan di semua jenjang dan jenis pendidikan. Kedua, meningkatkan kesejahteraan dan profesionalitas guru. Ketiga, pendayagunaan sarana dan prasarana pendidikan.

Pendidik berada di barisan terdepan dalam menciptakan mutu pendidikan. Pendidik berhadapan langsung dengan para peserta didik di kelas melalui proses belajar mengajar. Di tangan pendidiklah akan dihasilkan peserta didik yang bermutu, baik secara akademis, skill (keahlian), kematangan emosional dan moral serta spiritual. Dengan demikian, akan dihasilkan generasi masa depan yang siap hidup dengan tantangan zamannya.

Dengan demikian, seorang pendidik yang profesional jelas harus memiliki keahlian tertentu yang diperoleh melalui sebuah proses pendidikan maupun pelatihan khusus, dan terdapat unsur semangat pengabdian (panggilan profesi) dalam melaksanakan suatu pekerjaan. Pendidik merupakan kunci keberhasilan suatu lembaga pendidikan. Baik buruknya perilaku atau tata cara mengajar pendidik akan sangat mempengaruhi citra lembaga pendidikan. Tanpa adanya sumber daya pendidik yang profesional mutu pendidikan tidak akan meningkat.

Karena dalam pelaksanaan pendidikan sekolah sangat ditekankan adanya peningkatan mutu sebagai jawaban terhadap kebutuhan dan dinamika masyarakat yang sedang berkembang, sehingga peningkatan mutu dapat diwujudkan melalui pelaksanaan pendidikan. Pendidik merupakan suatu profesi, yang berarti suatu jabatan yang memerlukan keahlian khusus.

Pendidik melaksanakan tugas yang tidak dapat dilakukan oleh sembarang orang di luar bidang pendidikan. Tugas guru sebagai suatu profesi meliputi mendidik, mengajar dan melatih. Mendidik berarti meneruskan dan mengembangkan nilai-nilai hidup. Mengajar berarti meneruskan dan mengembangkan ilmu pengetahuan dan teknologi, sedangkan melatih berarti mengembangkan ketrampilan-ketrampilan pada peserta didik.

Pendidik memiliki kualifikasi akademik, kompetensi, sertifikat pendidik, sehat jasmani dan rohani, serta berusaha semaksimal mungkin mewujudkan tujuan pendidikan nasional. Kompetensi pendidik meliputi kompetensi pedagogik, kompetensi kepribadian, kompetensi sosial dan kompetensi profesional yang diperoleh melalui pendidikan profesi.

Masalah kompetensi profesional pendidik merupakan salah satu dari kompetensi yang harus dimiliki oleh setiap pendidik dalam jenjang pendidikan apapun. Pada zaman globalisasi ini kemajuan ilmu pengetahuan dan teknologi yang semakin canggih dan mengalami pergerakan yang sangat cepat. Profesionalisme dalam bidang tersebut sangat diharuskan, terutama profesionalisme pendidik. Pendidik yang peka dan tanggap terhadap perubahan-perubahan, pembaharuan serta ilmu pengetahuan dan teknologi yang terus berkembang sejalan dengan kebutuhan masyarakat dan perkembangan zaman.

Di sinilah tugas pendidik untuk senantiasa meningkatkan mutu pendidikan sehingga apa yang sampaikan kepada peserta didik jelas dan mudah diserap oleh peserta didiknya. Perlu disadari pula bahwa untuk dapat berlangsungnya kegiatan pendidikan di sekolah, unsur manusia merupakan unsur yang sangat penting, karena kelancaran pelaksanaan program-program sekolah tergantung kepada orang-orang yang melaksanakannya.

Sumber daya manusia sangat berperan dalam menentukan kemajuan suatu negara. Peningkatan kualitas SDM merupakan persyaratan mutlak untuk mencapai tujuan pembangunan. Kualitas SDM ditingkatkan melalui berbagai program pendidikan yang sistematis dan terarah berdasarkan kepentingan yang mengacu pada kemajuan ilmu pengetahuan dan teknologi (IPTEK) dengan dilandasi oleh keimanan dan ketakwaan (IMTAQ).

Kompetensi pendidik profesional meliputi kemampuan pendidik mengenal peserta didik yang dilayaninya secara mendalam, menguasai bidang studi secara keilmuan dan kependidikan dalam hal 
mengemas materi pembelajaran, kemampuan menyelenggarakan pembelajaran yang mendidik mulai dari perancangan sampai pemanfaatan hasil penilaian terhadap proses dan hasil pembelajaran serta pengembangan profesionalitas yang berkelanjutan.

Tim Departemen Agama RI mengungkapkan bahwa tugas kompetensi guru adalah mengajar, mendidik, melatih dan menilai/mengevaluasi proses dan hasil belajar mengajar, yang kesemuanya merupakan satu kesatuan yang terpadu dan utuh. Dengan demikian, guru sebagai pendidik, memberikan bantuan terhadap pemecahan masalah yang dihadapi peserta didik. Sedangkan tugas guru yang lain pada hakikatnya merupakan jalinan antara keterlaksanaan bidang pengajaran dan bidang umum lainnya.

Tugas dan peranan pendidik yang berkompetensi sesungguhnya sangat komplek, tidak terbatas pada saat berlangsungnya interaksi edukatif di dalam kelas yang lazim disebut proses belajar mengajar. Pendidik yang bertugas sebagai motivator, fasilitator, mediator serta administrator dan lain-lainnya sesuai dengan kompetensi yang dimiliki.

Tuntuntan akan pendidik yang profesional harus disertai dengan pemenuhan kebutuhan hak pendidik atas kesejahteraan atau penghasilan yang layak dan juga kesempatan guru untuk mengembangkan diri sesuai dengan yang diamanatkan dalam Undang-undang No 14 tahun 2005. Berdasarkan prinsip profesionalitas maka pemberdayaan profesi pendidik diselenggarakan melalui pengembangan diri yang dilakukan secara demokratis, berkeadilan, tidak diskriminatif, dan berkelanjutan dengan menjunjung tinggi hak asasi manusia, nilai keagamaan, nilai kultural, kemajemukan bangsa dan kode etik profesi. Dengan demikian pendidik disamping tugas pokoknya di dalam kelas juga harus mendapat kesempatan untuk mengembangkan dirinya sesuai dengan yang tercantum dalam pasal 14 yaitu memperoleh pelatihan dan pengembangan profesi dalam bidangnya.

Dengan demikian kepala madrasah harus mempunyai strategi dalam meningkatkan mutu pendidikan yang ada di MTs Negeri 5 Cirebon tersebut. Peneliti memilih MTs Negeri 5 Cirebon ini dikarenakan : (1) Peneliti ingin mengetahui bahwasannya strategi pendidik yang profesional dalam meningkatkan mutu pendidikan di madrasah tersebut, (2) Kurangnya sarana dan prasarana yang belum mendukung adanya peningkatan mutu pendidikan.

Strategi adalah suatu seni menggunakan kecakapan dan sumber daya suatu organisasi untuk mencapai sasarannya melalui hubungan yang efektif dengan lingkungan dalam kondisi yang paling menguntungkan. Konsep tersebut mengemukakan bahwa strategi lebih menekankan pada suatu situasi di mana pimpinan mampu mendayagunakan segenap sumber daya organisasi dengan tepat dan benar.

Strategi adalah kunci suksesnya dalam mencapai tujuan madrasah. Kepala madrasah yang baik adalah kepala madrasah yang memiliki strategi jitu dalam memajukan madrasahnya. Tanpa ada strategi maka program madrasah tidak akan berjalan. Starategi adalah langkah awal dan terpenting ketika pemimpin berniat memajukan madrasah.

Dalam hal ini, maka seorang pimpinan (leader) harus dituntut memiliki kepandaian dalam menguasai situasi dan kondisi yang dimiliki oleh organisasi, sehingga mampu menerapkan suatu pengembangan program dan menggerakkan sumber daya organisasi yang dimilikinya. Lebih lanjut Winardi mengemukakan bahwa strategi merupakan pola sasaran, tujuan atau maksud dan kebijakan utama serta rencana untuk mencapai tujuan tersebut. Konsep tersebut lebih menitikberatkan pada upaya pimpinan dalam menetapkan sasaran yang harus dicapai organisasi melalui suatu perencanaan yang akurat, matang dan sistematis.

Selanjutnya seorang pimpinan harus memperhatikan pentingnya operasionalisasi keputusan dasar yang dibuat dengan memperhitungan kemampuan organisasi di bidang anggaran, sarana, prasarana dan waktu, terakhir menciptakan umpan balik sebagai instrument ampuh bagi semua pihak yang terlibat dalam pelaksanaan strategi yang telah ditentukan itu untuk mengetahui apakah sasaran terlampaui, hanya sekedar tercapai atau mungkin bahkan tidak tercapai. Kesemuanya itu diperlukan sebagai bahan dan dasar untuk mengambil keputusan di masa depan.

Berdasarkan konsep tersebut, maka strategi merupakan suatu kesatuan rencana yang menyeluruh, komprehensif dan terpadu yang diarahkan untuk mencapai tujuan. Dengan demikian dapat disimpulkan bahwa strategi kepala madrasah merupakan rangkaian dari rencana sebagai sasaran, 
kebijakan atau tujuan yang ditetapkan oleh seorang kepala madrasah dalam pembelajaran sesuai dengan kondisi yang ada, sehingga mampu mewujudkan peningkatan mutu pembelajaran.

Suryosubroto mengemukakan bahwa "kepala sekolah sebagai seorang yang bertugas membina lembaganya agar berhasil mencapai tujuan pendidikan yang telah ditentukan, harus mampu mengarahkan dan mengkoordinasikan segala kegiatan." Pengertian lain mengenai kepala sekolah menurut Purwanto adalah seorang tenaga professional yang diberi tugas memimpin sekolah dimana diselenggarakan proses belajar mengajar, atau tempat dimana terjadi interaksi antara guru yang memberi pelajaran dan murid yang menerima pelajaran.

Kepala madrasah sebagai manajer pendidikan yang berada di madrasah memiliki peranan yang sangat penting dalam menentukan atau membawa madrasah yang dipimpinnya memperoleh mutu pembelajaran yang baik. Keadaan tersebut tentunya dapat diwujudkan dengan baik, apabila kepala madrasah mampu menciptakan strategi yang relevan dengan kondisi dalam meningkatkan mutu pembelajaran. Untuk mengetahui tentang pengertian strategi kepala madrasah, maka terlebih dahulu perlu dipahami mengenai pengertian tentang strategi itu sendiri.

Menurut https://kbbi.web.id/pimpin kepemimpinan adalah perihal memimpin atau cara memimpin. Sedangkan Wahjosumidjo Kepemimpinan diterjemahkan kedalam istilah sifatsifat, perilaku pribadi, pengaruh terhadap orang lain, pola-pola interaksi, hubungan kerjasama antar peran, kedudukan dari satu jabatan administratif, dan persepsi dari lain-lain tentang legitimasi pengaruh.

Kepemimpinan atau leadership dalam pengertian umum menunjukkan suatu proses kegiatan dalam hal memimpin, membimbing, mengontrol perilaku, perasaan serta tingkah laku terhadap orang lain yang ada dibawah pengawasannya. Kepemimpinaan merupakan kemampuan yang dipunyai seseorang untuk mempengaruhi orang lain agar bekerja mencapai tujuan dan sasaran.

Jadi, kepemimpinan adalah sebuah proses mengaktualisasikan kemampuan seseorang dalam rangka mempengaruhi, membujuk, memotivasi, maupun mengoordinasi untuk mencapai tujuan tertentu. Berkenaan dengan kepala madrasah, maka kepala madrasah perlu memposisikan diri sebagai seseorang yang mempunyai pengaruh kepada para pendidik serta dapat pula memberika motivasi kepada para pendidik untuk dapat bekerja dengan baik sejalan dengan visi, misi, dan tujuan yang akan dicapai oleh madrasah tersebut.

Di sudut lain, menurut Nawawi menjelaskan bahwa tugas pimpinan sebagai pembuat kebijakan bagi lembaga tertentu seperti sekolah dasar secara umum memberikan masukan mengenai kebutuhan guru. Sasaran yang ingin dicapai berkaitan dengan kompetensi mengajar guru meliputi merencanakan kegiatan belajar mengajar sesuai dengan strategi belajar aktif, mengelola kegiatan belajar mengajar yang menantang dan menarik, menilai kemajuan anak belajar, memberikan umpan balik yang bermakna, membuat dan menggunakan alat bantu mengajar, memanfaatkan lingkungan sebagai sumber belajar, membimbing dan melayani siswa yang mengalami kesulitan belajar terutama bagi siswa yang lamban dan yang pandai, mengelola kelas, sehingga tercipta lingkungan belajar yang menyenangkan dan menyusun serta mengelola catatan kemajuan anak.

Kepala madrasah merupakan sebagai figur kunci dalam mendorong perkembangan dan kemajuan madrasah. Sebagai seorang pemimpin di sebuah lembaga, untuk meningkatkan mutu pendidikan di madrasah maka ada beberapa peran seorang kepala madrasah. Kepala madrasah atau kepala sekolah sama-sama sebagai pemimpin lembaga pendidikan memiliki beberapa peran, seperti yang diungkapkan Nurkolis22 ada tujuh, yaitu:

Sebagai evaluator, yaitu harus melakukan langkah awal, yaitu melakukan pengukuran seperti kehadiran, kerajinan dan pribadi para pendidik, tenaga kependidikan, administrator sekolah dan siswa. Data hasil pengukuran tersebut kemudian ditimbang-timbang dan dibandingbandingkan yang akhirnya dilakukan evaluasi. Evaluasi yang biasa dilakukan, misalnya terhadap program, perlakuan pendidik terhadap siswa, hasil belajar, perlengkapan belajar dan latar belakang pendidik. Sebagai manajer, yaitu harus memerankan fungsi manajerial dengan melakukan proses perencanaan, pengorganisasian, menggerakkan dan mengkoordinasikan.Sebagai administrator, pemimpin memiliki dua tugas utama yaitu: Pertama, sebagai pengendali struktur organisasi yaitu 
mengendalikan bagaimana cara pelaporan, dengan siapa tugas tersebut dikerjakan dan dengan siapa berinteraksi dalam mengerjakan tugas tersebut. Kedua, melaksanakan administrasi substantif yang mencakup administrasi kurikulum, kesiswaan, personalia, keuangan, sarana, hubungan dengan masyarakat, dan administrasi umum.

Sebagai supervisor, supervisor adalah aktivitas menentukan kondisi/syarat-syarat yang esensial yang akan menjamin tercapainya tujuan pendidikan. Tugas kepala madrasah sebagai supervisor bahwa ia harus meneliti, mencari dan menentukan syarat-syarat mana saja yang diperlukan bagi kemajuan sekolahnya. Sebagai leader, yaitu harus mampu menggerakkan orang lain agar secara sadar dan sukarela melaksanakan kewajibannya secara baik sesuai dengan yang diharapkan pimpinan dalam rangka mencapai tujuan. Sebagai inovator, yaitu melaksanakan pembaharuan-pembaharuan terhadap pelaksanaan pendidikan berdasarkan prediksi-prediksi yang telah dilakukan sebelumnya. Misalnya inovasi berupa pembaruan kurikulum dengan memperhatikan potensi dan kebutuhan daerah tempat madrasah berada. Inovasi itu bisa dilakukan terhadap materi kurikulum (isi kurikulum) ataupun strategi proses belajar mengajar. Sebagai motivator, pemimpin harus selalu memberikan motivasi kepada guru dan tenaga kependidikan serta administrator sehingga mereka bersemangat dan bergairah dalam menjalankan tugasnya dalam rangka meningkatkan mutu pendidikan.

Dengan demikian, strategi kepala sekolah adalah serangkaian bentuk kegiatan membantu guru mengembangkan kemampuannya mengelola proses pembelajaran, maka strategi kepala sekolah menilai guru dalam mengelola proses pembelajaran merupakan salah satu kegiatan yang tidak bisa dihindarkan prosesnya. Penilaian kepala sekolah terhadap guru dalam mengelola proses pembelajaran sebagai suatu proses pemberian estimasi kualitas kinerja guru dalam mengelola proses pembelajaran, merupakan bagian integral dari serangkaian kegiatan supervisi akademik.

Dalam teori manajemen, pengawasan merupakan upaya untuk memastikan perencanaan dan pelaksanakan dilakukan dengan benar. Dalam konteks peningkatan kualitas pendidikan di Madrasah, maka supervisi memiliki peran yang strategis. Kepala Madrasah wajib memiliki kompetensi supervisi, karena di antara tugasnya adalah melakukan supervisi akademik terhadap guru. Begitu pun dengan Pengawas Madrasah.

Supervisi adalah segala bantuan dari para pemimpin pendidikan/ sekolah yang tertuju kepada perkembangan kepemimpinan guru-guru dan personil sekolah lainnya di dalam mencapai tujuantujuan pendidikan. Supervisi sesungguhnya dapat dilaksanakan oleh Kepala sekolah yang berperan sebagai supervisor, dan itu juga sesuai dengan keputusan menteri pendidikan dan kebudayaan nomor 0134/0/1977, yang mana menyebutkan bahwa yang termasuk kategori supervisor adalah Kepala sekolah, pemilik sekolah, dan para kepala sekolah di tingkat kabupaten/kota, serta staf di kantor bidang setiap provinsi.

Wahjosumidjo dalam bukunya "Kepemimpinan Kepala sekolah" mengungkapkan bahwa sesungguhnya dalam bab-bab peraturan pemerintah yang mengatur pelaksanaan Undangundang Nomor 2 Tahun 1989 tentang Sistem Pendidikan Nasional ditegaskan pula bahwa Kepala sekolah bertanggungjawab atas penyelanggaraan kegiatan pendidikan, sehingga dengan demikian Kepala sekolah mempunyai kewajiban melakukan pembinaan dalam arti berusaha agar pengelolaan, penilaian, bimbingan, kepala sekolahan dan pengembangan pendidikan dapat dilaksanakan dengan lebih baik.

Fungsi kepala sekolah / madrasah atau supervisi dalam pendidikan bukan hanya sekedar kontrol atau melihat apakah segala kegiatan telah dilaksanakan sesuai dengan rencana atau program yang telah ditetapkan, tetapi lebih dari itu. Supervisi dalam pendidikan mengandung arti yang luas, kegiatan supervisi mencakup penentuan kondisikondisi atau syarat-ayarat personal maupun material yang diperlukan terciptanya situasi belajar mengajar yang efektif dan usaha memenuhi syarat-syarat itu.

Adapun tujuan supervisi pendidikan antara lain: Membantu para pendidik mengembangkan proses belajar mengajar, Membantu guru-guru menterjemahkan kurikulum ke dalam bahasa belajar mengajar, Membantu guru-guru mengembangkan staf sekolah.

Peningkatan kompetensi mengajar guru merupakan suatu upaya yang dilakukan dalam meningkatkan profesional guru yang dimiliki, sehingga diperoleh peningkatan dengan dibuktikan oleh peningkatan pelayanannya sebagai pengajar. Dalam hal ini seorang guru diarahkan untuk 
memiliki kemampuan yang lebih baik. Peningkatan kompetensi mengajar guru dimaksudkan untuk mengembangkan suatu jaringan dan sistem pembinaan kreatif dengan melibatkan secara aktif seluruh pembina guru dalam suatu kegiatan peningkatan profesional terpadu. Peningkatan kompetensi mengajar guru dilakukan sebagai upaya untuk meningkatkan kualitas dan kesesuaian program pendidikan, baik kualitas mengajar guru, kualitas belajar siswa maupun kesesuaian bahan dan cara pengajaran dengan tuntutan kebutuhan siswa, masyarakat dan nasional.

Untuk mewujudkan itu semua, diterbitkannya Peraturan Pemerintah Republik Indonesia Nomor 74 tahun 2008 tentang Guru, bahwa persyaratan guru yang memperoleh sertifikat minimal berpendidikan S1/D4, memiliki empat kompetensi (kompetensi pedagogik, kompetensi kepribadian, kompetensi sosial dan kompetensi professional).

Ada beberapa kompetensi yang harus dimiliki oleh seorang pendidik, yaitu antara lain: Kompetensi Pedagogik, Kompetensi kepribadian, Kompetensi Sosial, Kompetensi Profesional.

\section{METODE}

Penelitian ini menggunakan metode kualitatif agar dapat mendeskripsikan keadaan bagaimana penerapan dan efektifitas strategi kepala madrasah dalam pengembangan kompetensi Profesional Guru untuk meningkatkan mutu pendidikan di MTs Negeri 5 Cirebon. Hal ini diperkuat oleh Muri, bahwa peneliti kualitatif ingin mendeskripsikan atau memberikan satu informasi / fenomena tentang sesuatu yang ditelitinya sesuai dengan kontek dan sesungguhnya sesuai apa adanya.

Penelitian ini merupakan jenis penelitian lapangan dengan pedekatan kualitatif. Dalam penelitian kualitatif data yang dikumpulkan bukan angka-angka, akan tetapi berupa kata-kata atau gambaran. Data yang dimaksud berasal dari wawancara, catatan lapangan, foto, dokumen pribadi dan lainnya.

Penelitian kualitatif ini digunakan untuk mengungkap data deskriptif dari informasi tentang apa yang mereka lakukan dan yang mereka alami terhadap fokus penelitian, yang bekaitan dengan strategi yang dilakukan kepala madrasah sebagai pemimpin dalam pengembangan kompetensi
Profesional Guru untuk meningkatkan mutu pendidikan di MTs Negeri 5 Cirebon.

Model case study / studi kasus ini akan membantu untuk mendapatkan informasi secara mendalam mengenai keefektifan strategi kepala madrasah dalam pengembangan kompetensi Profesional Guru untuk meningkatkan mutu pendidikan di MTs Negeri 5 Cirebon. Kemudian hasil dari studi kasus / case study ini bisa dinilai ketepatan penerapan strategi kepala madrasah dalam pengembangan kompetensi Profesional Guru untuk meningkatkan mutu pendidikan di MTs Negeri 5 Cirebon. Jika belum tepat atau menemukan beberapa kendala, apa saja kendala dan titik kelemahannya sehingga bisa menyebabkan kurangnya efektifitas penerapan strategi kepala madrasah dalam pengembangan kompetensi Profesional Guru untuk meningkatkan mutu pendidikan di MTs Negeri 5 Cirebon.

Dengan mengetahui kendala dan titik kelemahan strategi kepala madrasah dalam pengembangan kompetensi Profesional Guru untuk meningkatkan mutu pendidikan di MTs Negeri 5 Cirebon ini diharapkan bisa diperbaiki dan ditingkatkan kualitas strategi kepala madrasah dalam pengembangan kompetensi Profesional Guru untuk meningkatkan mutu pendidikan di MTs Negeri 5 Cirebon.

Seperti yang digambarkan oleh Sugiyono, pengumpulan data merupakan hal yang paling strategis dan tanpa mengetahui teknik pengumpulan data yang dipilih, maka tidak akan mendapatkan data yang memenuhi standar yang diharapkan. Oleh karena itu, dalam penelitian ini digunakan beberapa tekhnik pengumpulan data, yaitu: wawancara, observasi, dan Dokumentasi.

\section{HASIL DAN PEMBAHASAN}

\section{Strategis Kepala Madrasah dalam Pengembangan Kompetensi Profesional Guru Untuk Meningkatkan Mutu Pendidikan}

a) Memotivasi Para Guru MTs Negeri 5 Cirebon untuk Berkreasi dan Inovasi dalam Menggunakan Strategi Pembelajaran Aktif.

Kepala Madrasah MTs Negeri 5 Cirebon telah memberikan motivasi kepada 
guru dan staf / karyawan dengan cara menyetujui semua program yang dimiliki oleh guru pendidikan agama Islam, salah satu program tersebut adalah adanya program manasik haji yang merupakan salah satu strategi pembelajaran aktif yaitu metode demontrasi yang dimiliki oleh guru pendidikan agama Islam untuk peningkatan pembelajaran pendidikan agama Islam siswa agar siswa dapat memahami dan mengerti bagaimana tata cara haji. Dari strategi ini, ada peningkatan yang cukup drastis pada tahun pelajaran 2019/2020, karena pada tahun pelajaran sebelumnya tidak ada kegiatan semacam ini.

Strategi tersebut sejalan dengan pendapat Sudrajat, bahwa tugas pokok dan fungsi kepala sekolah / madrasah sebagai pemimpin pendidikan adalah menggerakkan staf dalam artian memotivasi staf melalui internal marketing dan memberi contoh eksternal marketing. Begitu juga sama dengan pendapat Mulyasa, bahwa motivasi merupakan suatu faktor yang cukup dominan dan dapat menggerakkan faktor-faktor lain ke arah efektifitas kerja tenaga kependidikan.

Dengan demikian, seorang kepala madrasah yang efektif lebih dari sekedar menjadi administrator atau manajer. Kepemimpinan kepala madrasah yang efektif membutuhkan totalitas penuh dengan pendekatan kreatif dalam bekerja, tidak tergantung, memiliki tujuan yang jelas, keaslian, fleksibel, dan ketertarikan yang luas. Pada masa mendatang, pendidikan membutuhkan prinsip kreatifitas. Pimpinan yang kreatif adalah pemimpin yang bersemangat, antusias, mantap, fleksibel, dan berdaya guna. Pemimpin yang kreatif mampu melayani yang lain, berani menegakkan kebenaran, berani mencoba sesuatu yang baru, mengambil inisiatif dan mewujudkannya.

b) Meningkatkan Profesionalisme para Guru MTs Negeri 5 Cirebon Melalui SeminarSeminar, Workshop, Penataran-Penataran, MGMP, Pelatihan Bahasa Inggris dan Komputer.
Pelaksanaan peningkatan profesionalisme para guru MTs Negeri 5 Cirebon dari tahun ke tahun ada peningkatan. Peningkatan tersebut diindikatori dari hasil pelaksanaannya yaitu para pendidik / guru dan staf / karyawan mampu memberikan pelayanan pendidikan kepada siswa dengan baik serta meningkatkan kinerja gurunya dalam membenahi materi dan metodologi pembelajaran tersebut.

Begitu juga efektivitas kepala MTs Negeri 5 Cirebon dari pelaksanaan strategi tersebut adalah guru bisa menerapkan sepuluh kompetensi dasar yang diperlukan dalam menjalankan tugas mengajar yaitu menguasai bahan ajar, mampu mengelola sumber belajar, mengelola kelas, menggunakan media, menguasai landasan pendidikan, mengelola interaksi belajar mengajar, menilai prestasi belajar siswa untuk kepentingan pengajaran, memahami prinsip-prinsip dan menerapkankan hasil penelitian guna keperluan pengajaran.

Strategi tersebut sesuai dengan strategi Suhardan dalam meningkatkan mutu pembelajaran, yaitu strategi tutor kolega yang merupakan forum diantara sesama guru, yang bertujuan untuk saling bertukar pengalaman dan pengetahuan dalam meningkatkan mutu mengajar, saling mengimbas pengetahuan dari guru yang satu keguru lain atau kepada sekelompok guru. Sama halnya pendapat Mulyasa, untuk meningkatkan profesional guru yang sifatnya khusus, bisa dilakukan oleh kepala sekolah dengan mengikutsertakan guruguru melalui seminar dan pelatihan yang diadakan oleh DEPDIKNAS maupun di luar DEPDIKNAS.

Hal tersebut dilakukan untuk meningkatkan kinerja guru dalam membenahi materi dan metodologi pembelajaran. Patterson sebagaimana dikutip Daryanto, bahwa untuk meningkatkan terhadap profesional guru, kepala sekolah / madrasah memberikan perhatian terhadap kemampuan cukup baik untuk mengelola kelas, sarana dan 
prasarana. Dengan demikian, kegiatan kepala sekolah / madrasah mendorong para guru MTs Negeri 5 Cirebon untuk mengikuti seminar maupun pelatihan bertujuan agar para guru MTs Negeri 5 Cirebon selalu mengetahui perkembangan terbaru dan meningkatkan keprofesionalannya.

c) Menerapkan Kedisiplinan Guru, Karyawan, dan Siswa (Stake Holder) Baik pada Waktu Masuk Sekolah, Pulang Sekolah, Maupun dalam Proses Belajar Mengajar.

Pelaksanaan kedisiplinan bagi para guru, karyawan, dan siswa MTs Negeri 5 Cirebon ada peningkatan. Penerapan kedisiplinan tersebut adalah bagian dari profesionalitas para guru dan karyawan dalam melaksanakan tugasnya. Implikasi dari peningkatannya adalah proses pembelajaran berjalan sesuai dengan jadwal yang telah dibuat dalam peraturan madrasah dan produktivitas kerja meningkat.

Kedisiplinan tersebut searah dengan ungkapan Mulyasa, kepala sekolah harus mampu menumbuhkan disiplin tenaga kependidikan, terutama disiplin diri (selfdiscipline). Sama halnya dengan pendapat Jorgenson sebagaimana dikutip Daryanto, bahwa keberhasilan sekolah dapat terwujud bila kepala sekolah diberikan otoritas yang penuh untuk memelihara budaya disiplin bagi semua guru dan staf.

d) Melaksanakan Supervisi

Supervisi pendidikan adalah hal yang sangat penting untuk dilakukan untuk meningkatkan mutu pendidikan. Mutu pendidikan sangat berkaitan erat dengan keprofesionalan guru dalam menghadapi permasalahan-permasalahan yang ada di dunia pendidikan baik pada masa saat ini atau masa yang akan datang. Berdasarkan hal tersebut pendidikan merupakan faktor yang penting karena pendidikan salah satu penentu mutu SDM (Sumber Daya
Manusia), dimana manusia dapat membina kepribadiannya dengan jalan mengembangkan potensi-potensi yang dimiliki sesuai dengan nilai-nilai yang ada didalam masyarakat.

Supervisi pendidikan, bukanlah hanya sebagai pelengkap didalam Administrasi pendidikan, akan tetapi merupakan hal yang sangat penting untuk dilaksanakan. Tidak dapat dipungkiri bahwa ada sebagian para guru yang kurang konsekuen dan kurang memenuhi pra syarat dalam pekerjaannya, serta rendahnya moral guru yang dapat mengakibatkan hilangnya kewibawaan dan kaburnya status, serta kurang terampilnya guru dalam menyampaikan pelajaran. Karena itu sangat diperlukan pengawasan dan pembinaan yang baik. Dengan kata lain bahwa supervisi sangat diperlukan.

Supervisi menjadi indikator peningkatan yang dilakukan oleh kepala madrasah MTs Negeri 5 Cirebon untuk memberikan layanan yang lebih baik pada mutu pembelajaran mata pelajaran terwujud pada sekolah yang Islami yang berdaya saing tinggi membentuk generasi shaleh cerdas unggul mandiri dalam bidang keilmuan dan teknologi. Supervisi dilakukan dalam rangka menjamin pembelajaran yang berkualitas. Artinya, bahwa keberhasilan pelaksanaan supervisi diukur dari peningkatan prestasi belajar siswa.

Strategi kepala Madrasah MTs Negeri 5 Cirebon tersebut sejalan dengan Peraturan Menteri Pendidikan Nasional Republik Indonesia Nomor 13 Tahun 2007, tentang Standar Kepala Sekolah/Madrasah dalam dimensi supervisi yaitu merencanakan program supervisi akademik dalam rangka peningkatan profesionalisme guru, melaksanakan supervisi akademik terhadap guru dengan menggunakan pendekatan dan teknik supervisi yang tepat, dan menindaklanjuti hasil supervisi akademik terhadap pendidik atau guru dalam rangka peningkatan profesionalisme guru. 
Jadi supervisi merupakan kegiatan kepala madrasah dalam upaya meningkatkan profesionalitas para guru MTs Negeri 5 Cirebon yang menitikberatkan pada bimbingan, arahan, dan bantuan kepada para guru MTs Negeri 5 Cirebon agar proses belajar mengajar berjalan dengan baik. Artinya dengan melakukan supervisi terhadap para guru, maka hasil belajar mengajar siswa/peserta didik akan baik dan meningkat.

e) Meningkatkan Kualitas Siswa Dengan Mengikutkan Perlombaan Baik Kurikuler Maupun Ekstrakurikuler.

\begin{tabular}{llr}
\multicolumn{1}{c}{ Bagi anak sekolah } & maupun \\
mahasiswa, & menekuni & kegiatan \\
ekstrakurikuler & merupakan & hal yang
\end{tabular} penting di samping aktivitas akademis. Pasalnya kegiatan ekstrakurikuler dapat memberikan berbagai manfaat bagi anak. Beberapa ahli sepakat kalau ekstra kurikuler penting untuk mendukung kemajuan anak di bidang akademis. Jadi meskipun orang tua ingin fokus pada kemajuan pendidikan anak, sebaiknya anak memiliki kegiatan sampingan yang positif untuk menyeimbangkan kehidupannya. Sebab belajar terus-menerus tanpa diselingi kegiatan lain yang sifatnya merilekskan pikiran juga akan memberikan beban secara psikologis kepada anak.

Penulis rangkum beberapa alasanalasan kenapa kegiatan ekstrakurikuler bermanfaat untuk anak sekolah ataupun mahasiswa. Yang pertama, peserta didik menjadi lebih aktif. Dengan mengikuti kegiatan ekstrakurikuler, memberikan ruang dan kesempatan kepada peserta didik untuk menjadi pribadi yang aktif dan produktif. Karena mereka menghabiskan waktu dan energi untuk kegiatan yang positif, para orang tua dan para guru bisa sedikit bernapas lega. Sebab kesempatan mereka untuk bersentuhan dengan hal-hal negatif di luar sekolah / madrasah juga jadi berkurang.

Yang kedua, Dalam kegiatan ekstrakurikuler umumnya peserta didik akan bertemu dengan teman-teman baru dan dalam beberapa hal harus mencoba bekerja sama dengan mereka. Bahkan ekskul yang tampaknya kurang dalam aspek sosialisasi seperti menjadi anggota perpustakaan pun tetap butuh interaksi dan sosialisasi dengan orang lain. Hal seperti ini akan mengajarkan anak untuk komunikasi dan koordinasi sejak dini. Dan pastinya ikut meningkatkan rasa percaya diri mereka dalam bersosialisasi. Mereka akan belajar untuk menghadapi dan menyelesaikan masalah dengan cara positif, dan pada akhirnya pengalaman bersosialisasi ini akan menjadikan mereka pribadi yang lebih terbuka dan tegar.

Yang ketiga, Salah satu sisi positif dari ekstrakurikuler yang tidak bisa diabaikan adalah kegiatan ini bisa menjadi wadah bagi anak untuk menyalurkan energi dan kreativitas dengan cara yang positif. Melalui kegiatan ekstrakurikuler anak jadi bisa menyalurkan minat. Mereka jadi terdorong untuk mengembangkan bakatnya.

Yang keempat, Ketika seseorang melakukan kegiatan yang disukai di antara serangkaian rutinitas yang harus dijalani setiap hari, kemampuan mereka dalam menghadapi stres juga semakin tinggi. Hal yang sama juga berlaku bagi anak-anak. Kegiatan sekolah dan tugas rumah yang padat bisa membuat mereka rawan terkena stres. Dan melakukan hal-hal yang menyenangkan di luar aktivitas sekolah bisa menjadi terapi anti depresi yang ampuh untuk mereka. Selama aktivitas ekstrakurikuler anak mendapat kesempatan untuk bersantai dan melepaskan ketegangan selama jam pelajaran.

Yang kelima, Dengan mengikuti aktivitas ekstrakurikuler anak jadi memiliki banyak kegiatan. Dan dengan memiliki aktivitas yang padat seperti ini mau tak mau mereka harus belajar untuk mengatur dan memprioritaskan waktu. Hal seperti ini akan berguna untuk mereka di masa depan.

Berkaitan dengan hal tersebut, siswasiswa MTs Negeri 5 Cirebon difasilitasi pembimbing-pembimbing yang kompeten 
dalam bidangnya. Dalam pelaksanaannya, ada peningkatan di tahun pelajaran 2019/2020 dibandingkan pada tahun pelajaran sebelum-sebelumnya, sehingga banyak sekali prestasi yang diperoleh siswa MTs Negeri 5 Cirebon.

Hal tersebut membuktikan, bahwa strategi kepala Madrasah MTs Negeri 5 Cirebon dalam rangka meningkatkan mutu pembelajaran, yaitu komitmen madrasah bergerak di bidang mutu peserta didik / siswa, oleh karena itu madrasah kerap kali berpartisipasi dalam berbagai lomba di tingkat propinsi maupun nasional.

f) Mengembangkan Budaya Akhlak yang Baik (Akhlakul Karimah) pada Segenap Warga Madrasah (Stake Holder) Melalui Keteladanan.

Akhlak merupakan cermin perbuatan dan tingkah laku pada diri seseorang. Akhlak yang baik dapat membentuk budi pekerti yang baik pada diri seseorang dalam pergaulan kehidupan sehari-hari serta melakukan amar ma'ruf nahi mungkar. Akhlak mencakup berbagai aspek kehidupan karena seseorang akan dilihat dari perilaku (akhlak) kesehariannya.

Hal tersebut telah diimplementasikan kepala MTs Negeri 5 Cirebon sebagai bukti peningkatan yang tertuang dalam salah satu misi MTs Negeri 5 Cirebon yaitu menumbuh kembangkan pengalaman ajaran Islam yang membentuk pribadi berakhlak karimah. Di samping itu, keramahan dan keteladanan kepala MTs Negeri 5 Cirebon terlihat dalam bentuk sikapnya yang disegani oleh guru, karyawan maupun siswa-siswa, karena memberikan contoh/teladan yang baik seperti berangkat madrasah paling awal dan pulang paling akhir dan bersalam-salaman terhadap guru-guru dan siswa-siswa.

Apa yang telah dilakukan kepala MTs Negeri 5 Cirebon tersebut senada dengan Peraturan Menteri Pendidikan Nasional Republik Indonesia Nomor 13 Tahun 2007 tentang Kompetensi Kepala Sekolah/Madrasah dalam dimensi kepribadian, yaitu berakhlak mulia, mengembangkan budaya dan tradisi akhlak mulia, dan menjadi teladan akhlak mulia bagi komunitas di sekolah/madrasah.

Jadi, kepala madrasah sebagai manajer, sangat memahami bagaimana caranya dalam meningkatkan kompetensi kepribadian, diantaranya dengan memberikan suri teladan kepada guru dan staf yang ada, mendorong untuk berprilaku yang baik, berakhlak mulia, jujur, dan dapat diteladani oleh peserta didik. Upaya tersebut sangat beralasan, karena sebagai kepala madrasah ia mempunyai tanggung jawab yang besar terhadap citra guru dan lingkungan yang ada di sekolahnya.

Citra guru yang baik menimbulkan kesan di masyarakat, bahwa madrasah tersebut adalah baik, namun apabila citra guru di mata masyarakat kurang baik, hal ini akan berakibat buruk bagi sekolahnya. Seperti dalam peribahasa "Setitik nila, rusak susu sebelanga”, untuk itu sebagai kepala madrasah harus menjaga citra guru, staf, dan peserta didik (stake holder) untuk memiliki perilaku yang baik.

g) Peningkatan Kualitas Sarana dan Prasarana yang Memadai untuk meningkatkan Mutu Pembelajaran di MTs Negeri 5 Cirebon.

Pembinaan terhadap lembaga pendidikan tidak akan berjalan dengan baik apabila tidak didukung dengan sarana dan prasarana yang memadai. Oleh karena itu, usaha untuk memenuhi penyelenggaraan pembinaan fasilitas pendidikan adalah salah satu fungsi yang harus senantiasa dikembangkan terus menerus.

Sarana dan prasarana adalah salah satu sumber daya yang menjadi tolak ukur mutu madrasah dan perlu peningkatan terus menerus seiring dengan perkembangan ilmu pengetahuan dan teknologi yang canggih. Sarana dan prasarana sangat perlu dilaksanakan untuk menunjang keterampilan peserta didik agar siap bersaing terhadap pesatnya teknologi.

Sarana dan prasarana merupakan bagian penting yang perlu disiapkan secara 
cermat dan berkesinambungan sehingga akan terjamin proses belajar mengajar yang lancar. Dalam hal ini sarana dan prasarana sangat mempengaruhi dalam proses belajar mengajar. Sedangkan saat ini sarana dan prasarana untuk pendidikan memang kurang memadai, bahkan banyak sarana dan prasarana yang tidak layak untuk proses belajar mengajar.

Ketika sarana dan prasarana sekolah atau madrasah tidak memadai maka akan mempengaruhi proses belajar mengajar yang dilaksanakan. yaitu akan menghambat proses mengajar. Guru akan kesulitan dalam memberikan serta menjelaskan materi yang akan disampaikan kepada peserta didik. Begitu juga dengan peserta didik akan kesulitan untuk memahami apa yang dijelaskan oleh guru. Oleh sebab itu, proses belajar mengajar tidak akan berjalan secara efektif dan efisien.

Masalah sarana dan prasarana pendidikan yang kurang memadai juga dapat disebabkan oleh ketidakpedulian sekolah terhadap perawatan fasilitas yang ada yang akan menjadikan buruknya sarana dan prasarana. Sikap acuh tak acuh dan tidak adanya pengawasan dari pemerintah banyak fasilitas di sekolah yang terbengkalai.

Dalam hal ini, kepala MTs Negeri 5 Cirebon melakukan peningkatan kualitas sarana dan prasarana yang pokok dan memadai untuk kelancaran pendidikan, khususnya dalam proses pembelajaran di kelas seperti gedung dengan 21 ruang kelas, 1 ruang laboratorium, 1 ruang laboratorium komputer, 1 ruang koperasi dan 1 ruang UKS, 1 Masjid, 1 ruang OSIS, 1 ruang BK, 1ruang perpustakaan serta 1 kantin.

Strategi kepala MTs Negeri 5 Cirebon senada dengan pendapat Suhardan dalam meningkatkan mutu pembelajaran, yaitu penyediaan fasilitas dukungan kelancaran mengajar belajar yang memadai.97 Sama halnya pendapat Patterson (2008), bahwa untuk meningkatkan terhadap professional guru, kepala sekolah memberikan perhatian terhadap kemampuan cukup baik untuk mengelola kelas, sarana dan prasarana.
Pengelolaan sarana dan prasarana sebagai alat bantu mengajar yang merupakan tanggung jawab kepala sekolah terhadap pengelolaannya.

2. Kendala yang Dihadapi dalam Mengembangkan Kompetensi Profesional Pendidik untuk Meningkatkan Mutu Pendidikan di MTs Negeri 5 Cirebon.

Indonesia adalah salah satu negara berkembang yang masih mempunyai masalah dalam dunia pendidikan. Di mana kualitas pendidikan di Indonesia masih kalah dengan negara-negara lain. Hal itu dapat dilihat dari laporan hasil survei Programme for International Student Assessment (PISA) 2018 yang diterbitkan pada Selasa (3/12/2019). Dalam kategori kemampuan membaca, sains, dan matematika, skor Indonesia tergolong rendah karena berada di urutan ke-74 dari 79 negara.

Penyebab rendahnya kualitas pendidikan di Indonesia secara umum yakni, pertama efektifitas, efisiensi, dan standaritas pengajaran pendidikan. Efektifitas pendidikan di Indonesia sangat rendah. Menurut hasil survey beberapa pakar pendidikan, salah satu penyebabnya adalah tidak adanya tujuan pendidikan yang jelas sebelum kegiatan pembelajaran dilaksanakan.

Hal ini menyebabkan peserta didik dan pendidik tidak tahu "goal" apa yang harus dihasilkan sehingga tidak mempunyai gambaran yang jelas dalam proses pendidikan. Sarana pembelajaran juga turut menjadi faktor semakin terpuruknya pendidikan di Indonesia, terutama bagi penduduk di daerah terbelakang. Namun, bagi penduduk terbelakang tersebut, yang terpenting adalah ilmu terapan yang benar-benar dipakai untuk hidup dan kerja.

Para guru kurang kompak dalam melaksanakan kegiatan atau program keagamaan. Kekompakan / kebersamaan akan memperingan kinerja atau program yang akan dilaksanakan dan hasilnya akan tercapai sesuai dengan harapan yang diinginkan. Dari kenyataan yang ada, di lingkungan MTs Negeri 5 Cirebon masih ada guru MTs negeri 5 Cirebon yang kurang memperhatikan kebersamaan, dan 
ini menjadi tugas penting kepala madrasah MTs negeri 5 Cirebon untuk segera menyelesaikannya agar tidak berlarut-larut yang berakibat pada terhambatnya peningkatan mutu pendidikan.

Untuk itu kepala madrasah MTs Negeri 5 Cirebon dengan keprofesionalannya melakukan sosialisasi peningkatan kualitas pendidikan di berbagai wilayah kerja, baik dalam pertemuanpertemuan resmi maupun melalui pelatihan awal sebelum melaksanakan kegiatan. Hal tersebut akan menambah pemahaman bagi peningkatan mutu pendidikan.

Sebagaimana yang telah dilakukan kepala MTs Negeri 5 Cirebon sesuai dengan pendapat Suhardan, yaitu penugasan yang diberikan oleh kepala sekolah terhadap guru diikuti dengan pembinaan bagaimana seharusnya guru menjalankan tugas di kelasnya. Pembinaan terhadap guru yang memperoleh tugas baru mendapatkan perhatian yang besar, seiring dengan perubahan kondisi kerja yang dihadapinya.

Selain itu, peserta didik kurang istiqomah atau konsisten. Pengembangan mutu pembelajaran adalah usaha meningkatkan mutu pendidikan. Tujuan pendidikan utamanya adalah untuk membentuk kepribadian. Dalam hal ini bertujuan untuk meningkatkan mutu pendidikan, mengembangkan anak didik menjadi pribadi Muslim tidaklah mudah seperti membalikkan telapak tangan, dikarenakan banyaknya perbedaan dan persamaan yang ada dalam diri anak didik.

Sebagaimana diketahui, bahwa dalam kesanggupan jasmani seseorang tidak sama dengan orang lain, demikian juga dengan halhal yang bersifat rohaniah, tidak sama dengan orang lain. Pendapat lain mengatakan kalau kita perhatikan siswa-siswi akan segera mengetahui bahwa mereka memiliki usia kalender yang sama dan kemampuan mentalnya tidak sama. Perbedaan yang ada dalam diri siswa tersebut dapat menjadi hambatan bagi pengembangan aspek-aspek anak didik itu sendiri, yang pada akhirnya merupakan hambatan bagi pengembangan mutu pendidikan. Karena anak didik adalah salah satu faktor pendukung dalam pengembangan pendidikan tersebut.
Peserta didik sebagai objek dalam pelaksanaan peningkatan mutu pendidikan di MTs Negeri 5 Cirebon. Jadi apabila peserta didik / siswa tidak mendukung program yang telah ditetapkan di madrasah maka akan menghambat tujuan yang ingin dicapai. Kesadaran siswa atau peserta didik untuk mengikuti peraturan madrasah dirasa kurang.

Kurangnya kesadaran orangtua dalam memotivasi belajar peserta didik. Peran orang tua atau wali siswa sangat penting bagi tercapainya mutu pendidikan, baik di madrasah maupun di rumah. Karena orang tua atau wali siswa merupakan suatu faktor yang cukup dominan dan dapat menggerakkan peserta didik ke arah efektivitas belajar. Di samping itu, peran guru juga sama dalam memotivasi peserta didik di madrasah dalam membentuk jiwa peserta didik yang bermutu dan berkualitas.

Oleh karena itu, kepala MTs Negeri 5 Cirebon harus bisa dan benar-benar mendongkrak orang tua atau wali peserta didik untuk memotivasi kepada mereka. Hal tersebut sudah terlihat dari solusi atau usahanya kepala MTs Negeri 5 Cirebon dalam tiap silaturrahimnya ke rumah orang tua atau wali peserta didik dalam rangka menjalin keharmonisan pihak madrasah dan orang tua agar tercipta suasana pendidikan yang religius tinggi. Di samping itu, memberi dorongan terhadap orang tua untuk memperhatikan belajar anaknya ketika di rumah agar nantinya visi dan misi madrasah dapat tercapai sesuai dengan yang diinginkan bersama.

Bentuk pelaksanaan kepala MTs Negeri 5 Cirebon tersebut sesuai dengan yang terkandung dalam Peraturan Menteri Pendidikan Nasional Republik Indonesia Nomor 13 Tahun 2007 tentang Kompetensi Kepala Sekolah/Madrasah dalam dimensi sosial, yaitu bekerja sama dengan pihak lain untuk kepentingan sekolah/madrasah, berpartisipasi dalam kegiatan sosial kemasyarakatan, dan memiliki kepekaan sosial terhadap orang atau kelompok lain. Jorgenson sebagaimana dikutip oleh Daryanto103, juga perpendapat bahwa keberhasilan sekolah dapat terwujud bila kepala sekolah diberikan otoritas yang penuh untuk melakukan kerjasama dengan masyarakat khususnya orang tua murid. 


\section{KESIMPULAN}

Berdasarkan hasil dan pembahasan sebelumnya, maka peneliti menyimpulkan sebagai berikut:

Strategi kepala madrasah MTs Negeri 5 cirebon dalam upaya pengembangan kompetensi professional guru untuk meningkatkan mutu pendidikan di MTs Negeri 5 Cirebon, yaitu: Pertama, Memotivasi guru untuk berkreasi dan berinovasi; Kedua, Meningkatkan profesionalisme gurudengan mengirim mereka ke seminar-seminar atau workshop-workshop; Ketiga, Menerapkan kedisiplinan guru, karyawan, dan siswa (stakeholder); Keempat, Melakukan atau melaksanakan supervise yang berkelanjutan; Kelima, Meningkatkan kualitas peserta didik dengan mengikutkan melibatkan peserta didik untuk mengikuti perlombaan baik kurikuler maupun ekstrakurikuler; Keenam, Mengembangkan budaya akhlak yang baik (akhlakul karimah) pada segenap warga madrasah (stake holder) melalui keteladanan; Ketujuh, Peningkatan kualitas sarana dan prasarana yang memadai bagi pembelajaran.

Kendala yang dihadapi kepala madrasah dalam upaya pengembangan kompetensi professional guru untuk meningkatkan mutu pendidikan di MTs Negeri 5 Cirebon, yaitu: Pertama, para guru kurang kompak dalam melaksanakan kegiatan atau program; kedua; Kedua, perbedaan potensi dan background keluarga yang ada dalam diri siswa tersebut dapat menjadi hambatan bagi pengembangan aspek-aspek anak didik itu sendiri, yang pada akhirnya merupakan hambatan bagi pengembangan mutu pendidikan agama Islam, ketiga, kurangnya kesadaran orangtua atau wali peserta didik dalam memotivasi belajar peserta didik.

\section{DAFTAR PUSTAKA}

\section{Buku}

Agus Wibowo, (2014) Manager \& Leader Sekolah Masa Depan. Yogyakarta: Pustaka Pelajar.
A Muri Yusuf, (2014) Metode Penelitian: Kuantitatif, Kualitatif, dan Penelitian Gabungan. Jakarta: Fajar Interpratama Mandiri.

Asep Suryana dan Suryadi, (2009). Pengelolaan Pendidikan. Jakarta: Dirjen Pendis Kemenag RI.

Buchari Alma. (2009) Guru Profesional, Bandung: Alfabeta.

Cicih Sutarsih, (2009) Etika Profesi. Jakarta: Dirjen Pendis Kemenag RI.

Dadang Suhardan, (2010). Supervisi Profesional (Layanan Dalam Meningkatkan Mutu Pembelajaran Di Era Otonomi Daerah). Bandung:_ALFABETA.

Daryanto, (2005). Administrasi Pendidikan. Jakarta: Rineka Cipta.

Dimyati dan Mudjiono, (2009). Belajar dan Pembelajaran, (Jakarta: Rineka Cipta.

Farida Sarimaya, (2009). Sertifikasi Guru. Bandung: Yrama Widya.

Hadari Nawawi, (1998) Administrasi Pendidikan, Jakarta: CV. Haji Masagung.

Hamzah B Uno. (2008) Profesi Kependidikan. Jakart: Bumi Aksara.

Hari Sudrajat, (2004). Manajemen Peningkatan Mutu Berbasis Sekolah. Bandung: Cipta Cekas Grafika.

Jamal Ma'mur Asmani, (2009). 7 Kompetensi Guru Menyenangkan dan Profesional. Yogyakarta: Power Books.

John M. Echol, Hasan Shadily, (1988) Kamus Inggris Indonesia. Jakarta: Gramedia.

Kemendikbud, (2014) Petunjuk Peningkatan Mutu di Sekolah Dasar (Jakarta: Kemendikbud.

Lexy J Moleong, (2010). Metodologi Penelitian Kualitatif, Bandung: PT Remaja Rosdakarya.

Lukman Ali, (1995). Kamus Besar bahasa Indonesia, Jakarta: Balai Pustaka. 
Mahmud Yunus, 1984). Kamus Arab Indonesia. Bandung: Al-Ma'arif.

Mansur Muslich, (2010) Sertifikasi Guru Menuju Profesionalisme Pendidik, Jakarta: Bumi Aksara.

Moh. Uzer Usman. (2008) Menjadi Guru Profesional. Bandung: Remaja Rosda Karya.

M. Ngalim Purwanto, (2003). Administrasi dan Supervisi Pendidikan. Bandung: PT. Rosdakarya.

Mujamil Qomar. (2007). Manajemen Pendidikan Islam. Malang: Erlangga.

Musfah, Jejen, (2015) Manajemen Pendidikan: Teori, Kebijakan dan Praktik. Jakarta: Kencana.

Mulyadi, (2007) Manajamen Berbasis Sekolah. Jakarta: Bumi Aksara.

Mulyasa, E. (2007). Menjadi Kepala Sekolah Profesional, Bandung: Remaja Rosda Karya.

Mulyasa, E. (2002) Manajemen Berbasis Sekolah. Bandung: Remaja Rosdakarya.

Ngalim Purwanto, (2004) Administrasi dan Supervisi Pendidikan. Bandung: Remaja Rosdakarya.

Nur Aedi. (2016) Manajemen Pendidikan \& Tenaga pendidikan. Yogyakarta: Gosyen Publishing.

Nurkolis. (2006) Manajemen Berbasis Sekolah. Jakarta: PT Grasindo.

Oemar Hamalik, (2004). Pendidikan Guru Berdasarkan Pendekatan Kompetensi. Jakarta: Bumi Aksara.

Oemar Hamalik, (2008). Proses Belajar Mengajar. Jakarta: Bumi Aksara.

Rohiat, (2006). Manajemen Sekolah: Teori Dasar dan Praktik. Bandung: PT. Refika Aditama.

R Ibrahim dan Nana Syaodih, (2003). Perencanaan Pengajaran. Jakarta: Rineka Cipta.

Sobri, (2009). Pengelolaan Pendidikan. Yogyakarta: Multi Pressindo.

Sugiyono, (2017) Metode Penelitian Pendidikan. Bandung, Alfabeta.
Sugiyono, (2017). Metode Penelitian Kuantitatif, Kualitatif, dan $R \& D$. Bandung, Alfabeta.

Sugiarto, Eko. (2015) Menyusun Proposal Penelitian Kualitatif dan Kuantitatif: Skripsi dan Thesis. Yogyakarta: Suaka Media.

Suharsimi Arikunto, (2002). Prosedur Penelitian (Suatu Pendekatan Praktek). (Jakarta: PT Rineke Cipta.

Suryosubroto, (2004). Manajemen Pendidikan di Sekolah. Jakarta: Rineka Cipta.

Syaiful Bahri Djamarah dan Aswan Zain, (2006). Strategi Belajar Mengajar. Jakarta: Rineka Cipta.

Tim Departemen Agama. (2001) Metodologi Pengajaran Agama. Jakarta: Depag RI.

Tim Redaksi Sinar Grafika, (2007). Undanng-Undang Sisdiknas 2003. Jakarta: Sinar Grafika.

Wahjosumidjo. (2008) Kepemimpinan Pengawas. Jakarta: Rajagrafindo Persada.

Wahjosumidjo, (2013). Kepemimpinan Kepala Sekolah. Jakarta: PT Raja Grafindo Persada.

Winardi, (2012). Dasar-Dasar Manajemen. Bandung: Mandar Maju.

Wina Sanjaya, (2008). Strategi Pembelajaran Berorientasi Standar Proses Pendidikan. Jakarta: Kencana.

\section{Jurnal}

Ak, Harnovinsah, (2020). Metodologi Penelitian. Pusat Bahan Ajar dan Elearning Universitas Mercu Buana, diakses pada Agustus 2020 pada pukul 14.35

Alhamid, Thalha, (2019). Instrumen Pengumpulan Data. STAIN Sorong. diakses pada 26 Agustus 2020 pukul 15.34

A.F. Djunaedi, (2005) filosofi dan Etika kepemimpinan dalam Islam, Jurnal AlMawarid Edisi XIII Tahun. Diakses pada 04 November 2020 pukul 13.19

Gusti Widya Hapsari dan Fuad_Mas'ud, (2018) Praktek Kepemimpinan Islam (Studi Fenomenologi pada Manajer Rumah Sakit PKU Muhammadiyah Temanggung), DIPONEGORO JOURNAL OF MANAGEMENT, diakses pada 04 November 2020 pukul 13.57 


\section{Websites}

Muhammad Utsman el-Muhammady, Pemurnian Tasawuf oleh Imam Al-Ghazali, www/ Scribd/com/doc/2917072/ diakses pada 19 September 2020 Pukul 12.15

https://kbbi.web.id/pimpin, diakses pada 12 September 2020 pukul 19.55

https://news.okezone.com/read/2018/08/21/1/19394 66/4-aspek-penting-dalamupayameningkatkan-mutu-pendidikan; diakses pada 07 November 2020 pukul 09:22 Undang - Undang Republik Indonesia Nomor 14 Tahun 2005 Tentang GURU dan DOSEN. 